Proceedings

\title{
The Ants Database of the Khibiny Polar Mountains ${ }^{\dagger}$
}

\author{
Irina V. Zenkova ${ }^{1, *}$, Zalimkhan M. Yusupov ${ }^{2}$ and Irina M. Shtabrovskaya ${ }^{1}$ \\ 1 Institute of North Industrial Ecology Problems, Kola Science Center, Russian Academy of Sciences; 14a, \\ Akademgorodok, Apatity, 184209, Russia; i.zenkova@inep.ksc.ru \\ 2 A.K. Tembotov Institute of Ecology of Mountain Territories, Russian Academy of Sciences; 37A, I. Armand \\ str., Nalchik, 360051, Russia; yzalim@mail.ru \\ * Correspondence: i.zenkova@inep.ksc.ru; Tel.: +7(953)3007140 \\ + Presented at the 1st International Electronic Conference on Entomology (IECE), 1-15 July 2021; Available \\ online: https://iece.sciforum.net/.
}

Citation: Zenkova, I.V.; Yusupov, Z.M.; Shtabrovskaya, I.M. The Ants Database of the Khibiny Polar Mountains, in Proceedings of the 1st International Electronic Conference on Entomology, 1-15 July 2021, MDPI: Basel, Switzerland, doi:10.3390/IECE-10502

Published: 1 July 2021

Publisher's Note: MDPI stays neutral with regard to jurisdictional claims in published maps and institutional affiliations.

Copyright: (C) 2021 by the authors. Submitted for possible open access publication under the terms and conditions of the Creative Commons Attribution (CC BY) license (https://creativecommons.org/license s/by/4.0/).

\begin{abstract}
Based on the results of entomological studies in thirteen natural and anthropogenic disturbed ecosystems of the Khibiny polar mountains in 2014-2018, a Database on ants was created. The Database contains information on 18 collected ant species and three non-captured species known in Khibiny from reports of the first Scientific Mountain Base in the 1930s. A total of 21 species make up $82 \%$ of known myrmecofauna of the Kola Subarctic. The collected ants belong to 4 genera and 2 subfamilies of the family Formicidae, including 13 species of the subfamily Formicinae and 5 species of the subfamily Myrmicinae. Seven Formica species we are reporting in Khibiny for the first time (F.aquilonia, F. forsslundi, F. polyctena, F. rufibarbis, F. sanguinea, F. suecica and F. truncorum). Among them, the boreo-alpine ant F. suecica is rare in Fennoscandia and is a red-listed species in Finland. Three wood ants (F. aquilonia, F. lugubris and F. polyctena) are included in European Red List (1992) in the vulnerable category and in IUCN Red List of Threatened Species (1996) as near-threatened species.
\end{abstract}

Keywords: Khibiny polar mountains; ants; Myrmicinae; Formicinae; checklist; database

\section{Introduction}

The Khibiny mountains, with the maximal altitude about $1200 \mathrm{~m}$ asl, located in 150

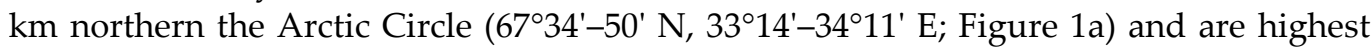
peaks in the Kola Subarctic. The specificity of the mountain climate, rocks, soils and the altitudinal zonation of these abiotic factors $[15,18,19,24]$ determine the uniqueness of the mountain flora and fauna. To preserve the unique mountain nature a most of the territory of Khibiny has received a protected status of the National Park in 2018. Within the project on assessment of a polar mountains biodiversity, we have been studying the invertebrate fauna of Khibiny since 2008 and have identified about 450 species of arachnids, insects, earthworms, gastropods, and centipedes [25]. For the most diversity taxa we create the databases. In this article, we report a Database on the local myrmecofauna of Khibiny mountains, registered in 2021.

\section{Materials and Methods}

\subsection{Fieldworks}

The ants were collected in 2014-2018 in different parts of Khibiny mountains: western (Yumechorr Mt), eastern (Suolaiv Mt), and central part (Yuksporr and Kuelporr Mts), in ten natural and three disturbed ecosystems (Figure 1b). Natural biotopes were selected on slopes of different exposures, in four main vegetative belts in the height range from 235 to $730 \mathrm{~m}$ above sea level: mountain taiga (rare-stand spruce and pine forests), forest-tundra (birch crooked forests), lower tundra and high-mountain tundra with fragmentary vegetation. Disturbed ecosystems were represented by 6 -year-old pine forests 
felling and 5-year-old burnt forest and burnt felling, in the intermountain valley of the Kuniyok River, $220 \mathrm{~m}$ asl, in the north of Khibiny. The altitude and coordinates of each biotope were measured using the Garmin navigator eTrex-30.

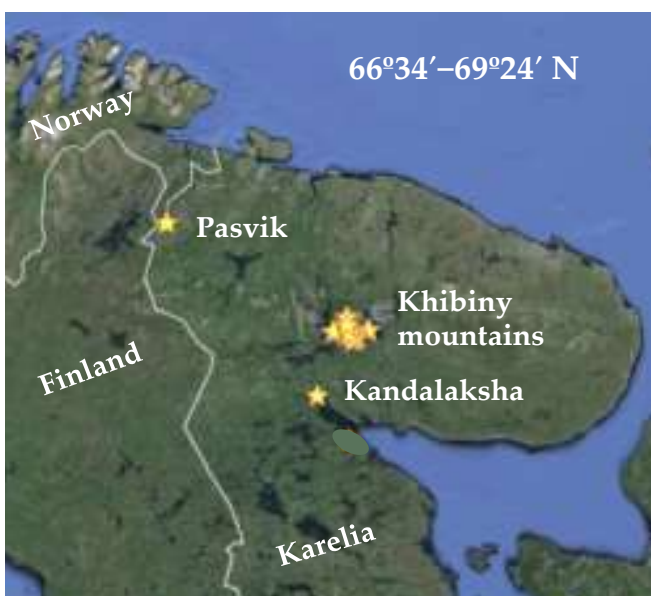

(a)

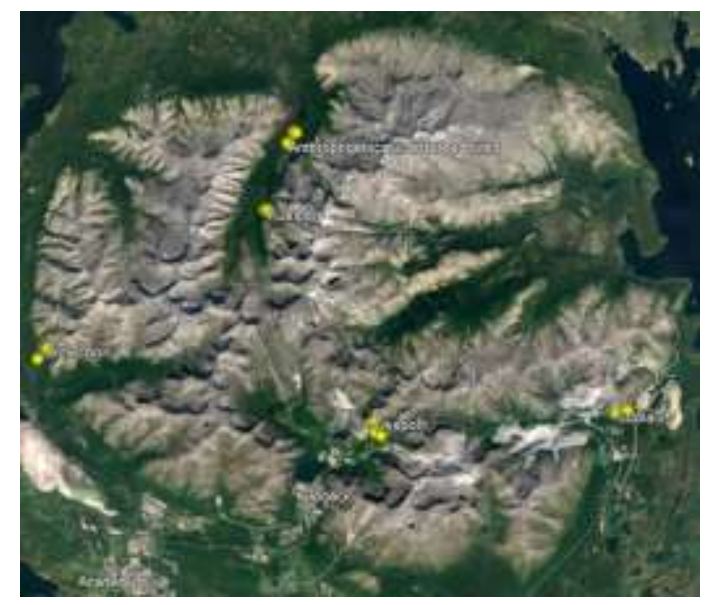

(b)

Figure 1. Location of Khibiny mountains and other areas of the Kola Subarctic with studied myrmecofauna (a) and mountains investigated in Khibiny (b). "Pasvik" and "Kandalaksha" Nature Reserves (a) - the literature data, Khibiny mountains (b) - own data.

The ants were collected from June to August-September (during 60-95 days) using $500 \mathrm{ml}$ plastic traps with $4 \%$ formaldehyde. The replication of traps in each biotope was 30-fold: three lines of 10 traps with a distance of 10 meters between the traps and the lines.

The temperature $\left({ }^{\circ} \mathrm{C}\right)$ and humidity $(\%)$ of atmospheric air and soil depth of $5 \mathrm{~cm}$ were measured daily in each biotope during the period of ant capture, using automatic sensors (recorders) with a measurement range from -25 to $+40{ }^{\circ} \mathrm{C}$ and from 1 to $100 \%$ [21].

\subsection{Species identification}

All collected ants were identified by the second author using the stereomicroscope STEMI 2000 and different keys [4, 5, 20, 22]. The systematic and nomenclature was given according to the world catalog of ants [1]. All material is stored in Myrmecological Collection of Tembotov Institute of Ecology of Mountain Territories RAS, Nalchik.

\subsection{A Database creating}

Based on the results of species identification, a checklist of ants of the Khibiny mountains was compiled. The distribution of ants in Khibiny was mapped in the ArcGIS software package (ver 10.4) of the Russian company Esri CIS. The checklist was compared with well-studied ant fauna of two Nature Reserves located in different parts of the Kola Subarctic: in north-west, on the border with Norway and Finland (the trilateral "Pasvik" Reserve, $240 \mathrm{~km}$ from the Khibiny mountains), and on the southern White Sea coast ("Kandalaksha" Reserve, $90 \mathrm{~km}$ from the Khibiny) (Figure 1a).

We studied the lists of ants published in the Reports of the first Mountain Scientific Base in the 1930s [8], and later, during the entomological survey of Khibiny mountains before the creation of the National Park [26]. We also took into account a recent critical review of the order Hymenoptera of North-Western Russia [16].

\section{Results}

\subsection{Taxonomic part of a Database}


The created Database is called "Local Fauna of ants (Hymenoptera, Formicidae) of the Khibiny mountains" and contains information on 18 ant species collected by the authors in 2014-2018, and three non-collected species known in Khibiny from Reports of the first Scientific Mountain Base in the 1930s [8]. A total of 21 species from 4 genera and 2 subfamilies, including 16 species of the subfamily Formicinae and 5 species of the subfamily Myrmicinae (Table).

Table. Checklist of ants inhabiting Khibiny polar mountains and other areas of Kola Subarctic.

\begin{tabular}{|c|c|c|c|c|c|}
\hline \multicolumn{3}{|c|}{ Taxonomy } & \multicolumn{3}{|c|}{ Finds } \\
\hline Subfamily & Genera & Species & Khibiny mountains & Pasvik Reserve $^{2}$ & Kandalaksha Reserve $^{3}$ \\
\hline \multicolumn{6}{|c|}{ Formicinae Latreille 1809} \\
\hline \multicolumn{6}{|c|}{ Camponotus Mayr, 1861} \\
\hline & & C. herculeanus (Linnaeus 1758) & $+(5)$ & + & + \\
\hline \multicolumn{6}{|c|}{ Formica Linnaeus, 1758} \\
\hline & & F. aquilonia Yarrow $1955^{* *}$ & $+(5)$ & + & + \\
\hline & & F. exsecta Nylander 1846 & $+(3)$ & + & + \\
\hline & & F. forsslundi Lohmander $1949^{* *}$ & $+(1)$ & + & no data \\
\hline & & F. fusca Linnaeus 1758 & $+(2)$ & + & + \\
\hline & & F. gagatoides Ruzsky 1904 & $+(8)$ & + & + \\
\hline & & F. lemani Bondroit 1917 & $+(9)$ & + & + \\
\hline & & F. lugubris Zetterstedt 1838 & $+(2)$ & + & + \\
\hline & & F. picea Nylander $1846^{1}$ & not found & + & no data \\
\hline & & F. polyctena Foerster $1850^{* *}$ & $+(1)$ & no data & + \\
\hline & & F. pratensis Retzius $1783^{1}$ & not found & no data & + \\
\hline & & F. rufa Linnaeus $1761^{1}$ & not found & no data & no data \\
\hline & & F. rufibarbis Fabricius $1793^{*, * * *}$ & $+(1)$ & no data & no data \\
\hline & & F. sanguinea Latreille $1798^{* *}$ & $+(2)$ & + & + \\
\hline & & F. suecica Adlerz $1902^{* *}$ & $+(2)$ & no data & no data \\
\hline & & F. truncorum Fabricius $1804^{* *}$ & $+(3)$ & + & + \\
\hline \multicolumn{6}{|c|}{ Myrmicinae Lepeletier de Saint-Fargeau, 1835} \\
\hline & \multicolumn{5}{|c|}{ Leptothorax Mayr, 1855} \\
\hline & & L. acervorum (Fabricius 1793) & $+(10)$ & + & + \\
\hline & \multicolumn{5}{|c|}{ Myrmica Latreille, 1804} \\
\hline & & M. lobicornis Nylander 1846 & $+(12)$ & + & + \\
\hline & & M. rubra (Linnaeu, 1758) & $+(2)$ & no data & + \\
\hline & & M. ruginodis Nylander 1846 & $+(10)$ & + & + \\
\hline & & M. sulcinodis Nylander 1846 & $+(9)$ & + & + \\
\hline 2 subfamily & 4 genera & 21 species & 18 species & 15 species & 16 species \\
\hline
\end{tabular}

Note. Species collected in a single copy $\left(^{*}\right)$; for the first time in Khibiny mountains $\left(^{* *}\right)$ or in the Kola Subarctic $\left(^{* * *}\right)$. In parentheses the number of biotopes with captured species is shown. The literature data: ${ }^{1}[8],{ }^{2}[11,12-14],{ }^{3}[2,23]$.

Based on collected materials, the habitation of 12 previously known ant species is confirmed [8, 26] and seven Formica species (F. aquilonia, F. forsslundi, F. polyctena, F. rufibarbis, F. sanguinea, F. suecica and F. truncorum) have been recorded in Khibiny for the first time (Table), including two species (F. forsslundi and $F$. fusca) whose distribution in such northern latitudes has been questioned [16].

Three wood Formica ants (F. aquilonia, F. lugubris and F. polyctena) are included in the European Red List (1992) in the vulnerable category [7] and in the IUCN Red List of Threatened Species (1996) as near-threatened species [10], so are subject to protection everywhere. Our researches in Khibiny also confirm the existence of Formica suecica in the Kola Subarctic, which previously had been mentioned only for the White Sea coast in 
1913 [9]. This boreo-alpine ant is rare in Fennoscandia and a red-listed species in Finland [17].

The find of the European-West Siberian thermophilous and light-loving species Formica rufibarbis, locally distributed in Fennoscandia up to the latitude $62^{\circ} \mathrm{N}$ [3], is the first to the polar myrmecofauna.

\subsection{Attributive part of a Database}

The attribute table contains the following data for each ant find: the geographical coordinates, the slopes exposure, the mountain belt, the altitude above sea level, the type of habitat, the timing and methods of capture. The temperature and humidity of the atmospheric air and the litter, measured during the ants' collection, are indicated. Quantitative characteristics include the number of captured females, males, worker ants, and juvenile stages.

These data showed the greatest diversity of ants in ecosystems of the birch forests belt at $300-500 \mathrm{~m}$ altitude (14 ant species in total) as ecotone between the taiga and tundra mountain belts (12 species in each).

\subsection{Biological table of a Database}

This extensive table is compiled on the basis of numerous literary and Internet sources. It contains arealogical, zoogeographic, biotopic, biomorphological and trophic characteristics of each ant species, its hydro-, thermo-, and photo- preferences, the limits of cold resistance, the specifics of nest construction, and other environmental information.

Most ant species in Khibiny mountains have extensive Trans-Palearctic ranges and belong to the boreal faunogenetic group and the biomorphological group of herpetobionts. Despite the greater species richness of Formicinae subfamily, the more cold-resistant Myrmicinae species are widespread in the Khibiny ecosystems. At the same time, the presence of a significant number of stenotopic Formica species with different ecological preferences indicate the heterogeneity of habitat conditions within this polar mountains.

\section{Discussion}

According to the previous myrmecological studies in Khibiny in the 1930s and 1990s, t he checklist of ant includes 14 species: nine Formicinae species (C. herculeanus, $F$. exsecta, F. fusca, F. gagatoides, F. lemani, F. lugubris, F. picea, F. pratensis, and F. rufa) and five Myrmicinae species (L. acervorum, M. lobicornis, M. rubra (= M. laevinodis), M. ruginodis, and M. sulcinodis) [8, 26]. Later, Paukkunen and Kozlov [16] doubted the existence of four Formica species (F. forsslundi, F. fusca, F. pratensis, and F. rufa) in such northern latitudes referring to the Swedish catalog of ants [6].

We did not find three Formica species (F. picea, F. pratensis, and F. rufa) from Fridolin's list [8], although the former lives in the "Pasvik" Nature Reserve in $240 \mathrm{~km}$ north-west of Khibiny [12-14], and the second species in the "Kandalaksha" Nature Reserve, $90 \mathrm{~km}$ south of Khibiny [2]. But we confirmed the presence of controversial ants $F$. forsslundi and F. fusca, and added seven species to the checklist of Khibiny (Table). Among them, four red-listed wood ants (F. aquilonia, F. lugubris, F. polyctena and F. sueci$c a)$, the protection of which and their polar habitats seems possible in the borders of the Khibiny National Park founded in 2018.

So, the present local ant fauna of Khibiny counts 18 species and is comparable with myrmecofaunas of the two most studied territories of Kola Subarctic, such as the "Pasvik" and "Kandalaksha" Nature Reserves (Figure 1), for which 17 and 18 ant species are known, correspondingly [2,11-14, 23]. However, only 13 ant species are shared to Khibiny and both reserves. Additionally, two species (M. rubra and F. polyctena) are common for Khibiny and "Kandalaksha" Reserve and F. forsslundi is common for Khibiny and "Pasvik" Reserve. 


\section{Conclusions}

Based on the results of field studies in 2014-2018, a Database on ants of the Khibiny polar mountains was created. It's including 18 confirmed species. The findings of three more species, known only from the literature, require further research. These species, is possible, will be identified in the materials collected in a dozen other mountain biotopes in recent years (the data is still being processed). Thus, the Database will be constantly updated. Taking into account, the current local fauna of the Khibiny mountains includes more than $80 \%$ species of the regional myrmecofauna, we don't expect a significant addition to the submitted checklist. However, increasing the number of studied mountain ecosystems and their inclusion in the Database will allow identifying more statistically reliable trends in the ant distribution within the Khibiny mountains and in their altitude belts.

\section{Patents}

The Database was registered in the "Rospatent" Federal Service for Intellectual Property of Russia (https://rospatent.gov.ru/). Patenting is confirmed by a Certificate № 2021620847 from April 26, 2021 (in Russian) (Figure 2).

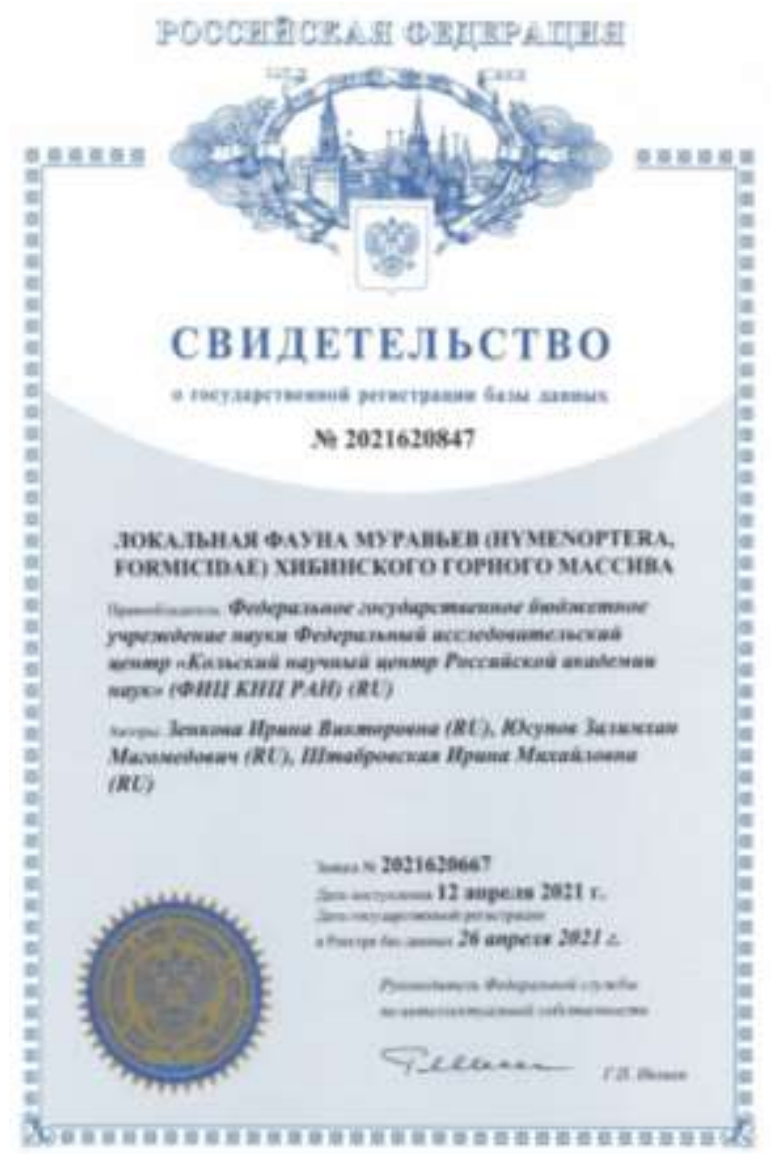

Figure 2. The Database Certificate.

Author Contributions: planning and organization of expeditions, I.Z.; collection of ants, I.Z., I.S.; identification of ants, Z.Yu.; compilation of a checklist, Z.Yu., I.Z.; data analysis, I.Z., I.S.; construction of a map-scheme of ants distribution, I.S.; preparation of materials and documents for registration of a Database, I.Z., Z.Yu., I.S.; writing and editing of this article, I.Z., Z.Yu., I.S. All authors have read and agreed with the current version of article. 
Funding: This research was conducted within the framework of INEP KSR RAS scientific project № A18-118021490070-5. The Database was registered with the financial support of the Russian Foundation for Basic Research (project № 20-34-90135).

Acknowledgments: The authors express the gratitude to the company «NauchPerevod.ru» (https://научныепереводы.pф) for the English language editing service.

Conflicts of Interest: The authors declare no conflict of interest. The funders had no role in the design of the study; in the collection, analyses, or interpretation of data; in the writing of the manuscript, or in the decision to publish the results.

\section{References}

1. Bolton, B. An online catalog of the ants of the world. 2020, Ver. 5.21. Available online: https://antcat.org (accessed on 10.06.2021).

2. Byzova, Yu.B.; Uvarov, A.V.; Gubina, V.G. Soil invertebrates of White Sea islands of the Kandalaksha Reserve. Moscow, Nauka Publ. House. 1986, 312.

3. Collingwood, C.A. Formicidae of Fennoscandia and Denmark. Fauna Entomologica Scandinavica. 1979, 1-156.

4. Czechowski, W.; Radchenko, A.; Czechowska, W.; Vepsäläinen, K. The ants of Poland with reference to the myrmecofauna of Europe. Fauna Poloniae (Warszawa) Natura Optima Dux Foundation. 2012, 496.

5. Dlussky, G.M. Ants of the genus Formica (Hymenoptera, Formicidae). Moscow, Nauka Publ. House. 1967, 236.

6. Douwes, P.; Abenius, J.; Cederberg, B.; Wahlstedt, U.; Hall, K.; Starkenberg, M.; Reisborg, C.; Östman, T. Nationalnyckeln till Sveriges flora och fauna. Steklar. Myror - getingar. Hymenoptera: Formicidae - Vespidae. Art Data banken. SLU Uppsala. 2012, 1-382.

7. European Red List of Globally Threatened Animals and Plants .New York, United Nations. 1992, 1-153.

8. Fridolin, V.Yu. Animal and plant community of the Khibiny Mountainous Country. Biocenotic research in $1930-$ 1935. Proceedings of the Kola Base of the USSR Academy. Moscow-Leningrad, Nauka Publ. House. 1936, 295.

9. Frey, R. En resa till Kola-halfön. Terra, Helsingfors. 1915, 111-126.

10. IUCN Red List of Threatened Species (1996). 2020, Ver. 2. Available online: https://www.iucnredlist.org (accessed on 25.05.2021).

11. Makarova, O.A. (ed.) Annals of Nature of Pasvik State Nature Reserve (Ryazan). Ryazan State Pedagogical University. 2005, 148.

12. Mershchiev, A.V. Northern taiga ant fauna of the Pasvik Nature Reserve and its surroundings. In: Evdokimova G.A., Vandysh O.I. (eds.). Environmental problems of the North. Apatity, Kola Science Center. 2006, 163-165.

13. Mershchiev, A.V. Comparative analysis of seasonal and daily dynamics of road systems in three species of forest ants Formica aquilonia, F. lugubrisand, F. truncorum (Hymenoptera, Formicidae, Formica s. str.) in vicinity of the Pasvik Nature Reserve. Ecology, evolution and taxonomy of animals. Ryazan, Department of Zoology and Methods of Teaching Biology, RSU. 2007, 93-116.

14. Mershchiev, A.V. The research of species composition and occurrence, biotope distribution of ants and development of myrmecological monitoring in the territory of Trilateral Park «Pasvik-Inari». Proceedings of the State nature reserve Pasvik (Pasvik Zapovednik). 2008, 41-52.

15. Mineralogy of the Khibiny massif. Moscow, Nauka Publ. House. 1978, 1, 228; 2, 586.

16. Paukkunen, J.; Kozlov, M.V. Stinging wasps, ants and bees (Hymenoptera: Aculeata) of the Murmansk region, Northwest Russia. Entomologica Fennica. 2015, 53-73. DOI: 10.33338/ef.51282.

17. Paukkunen, J.; Paappanen, J.; Leinonen, R.; Punttila, P.; Pöyry, J.; Raekunnas, M.; Teräs, I.; Vepsäläinen, K.; Vikberg V. Stinging wasps, bees and ants Aculeata. In Hyvärinen E., Juslén A., Kemppainen E., Uddström A. \& Liukko U.-M. (eds). The 2019 Red List of Finnish Species. Helsinki, Ministry of the Environment \& Finnish Environment Institute. 2019. 451-465.

18. Pereverzev, V.N. Genetic features of soils in altitudinal natural zones of the Khibiny Mountains. Eurasian soil science. 2010, 509-518.

19. Ponomareva, V.V. Materials on the study of organic matter in soils of the Khibiny mountain massif. Proceedings of the Kola Base of the USSR Academy of Sciences. 1940, 5-30.

20. Radchenko, A.G.; Elmes, G.W. Myrmica ants (Hymenoptera: Formicidae) of the Old World. Fauna Mundi 3. Warsaw: Natura Optima Dux Foundation. 2010, 790.

21. Recorders (loggers) of temperature and humidity. Available online: https://gigrotermon.ru/ (accessed on 10.04.2019). 
22. Seifert, B.; Schultz, R.A taxonomic revision of the Formica rufibarbis Fabricius, 1793 group (Hymenoptera: Formicidae). Myrmecological News. 2009, 255-272.

23. Uvarova, L.A.; Uvarov, A.V. Materials to the study of the ant fauna of the northern archipelago of Kandalaksha bay. Gilyarov M.S. (ed.). Fauna and ecology of invertebrates. Moscow, Moscow State Pedagogical Institute. 1976, 158.

24. Yakovlev, B.A. Climate of the Murmansk Region. Murmansk, Murmansk Publ. House. 1961, 24-27.

25. Zenkova, I.V. The diversity of soil fauna of the Khibiny Mountains (the results of ten-year researches). Proceedings of Fersman scientific session of the Kola Scientific Center of the Russian Academy of Sciences. 2020, 195-200.

26. Zryanin, V.A. A systematic list of insect species identified in the Khibiny and Lovozero tundra. Family Formicidae. Ecological and economic justification of the Khibiny National Park. Apatity. 1999. Available online: http://hibiny.info/documents/eeo (accessed on 05.09.2021). 